\title{
Produksi Miselium Jamur Ling ZHI (Ganoderma lucidum) Dalam Medium Air Kelapa Tua Dan Tauge Extract Broth Dengan Metode Kultur Terendam Teragitasi
}

\author{
Ayu Rahmawati Sulistyaningtyas ${ }^{1}$ dan Agung Suprihadi ${ }^{2}$ \\ ${ }^{1}$ Universitas Muhammadiyah Semarang, Jl. Kedungmundu Raya No. 18, Semarang, 50273, Indonesia \\ ${ }^{2}$ Universitas Diponegoro, J1. Prof. Soedarto, S.H Tembalang, Semarang, 50275, Indonesia \\ Email : ayurs@unimus.ac.id
}

\begin{abstract}
Abstrak
Jamur ling zhi (Ganoderma lucidum) sudah mulai dibudidayakan secara intensif di Indonesia. Masalah yang sering dihadapi dalam budidaya jamur ling zhi adalah kesulitan dalam penyediaan bibit. Proses penyediaan bibit jamur biasanya dilakukan secara konvensional menggunakan media agar. Metode konvensional akan membutuhkan biaya dan waktu produksi yang banyak sehingga diperlukan metode pembibitan baru yaitu kultur terendam teragitasi. Kultur terendam miselium dari kultur murni langsung dapat ditanam pada media tanam jamur. Penelitian ini bertujuan untuk mengetahui perbandingan produksi miselium jamur ling zhi dalam medium air kelapa tua dan tauge extract broth dengan metode terendam teragitasi. Parameter utama penelitian meliputi berat kering miselium, sedangkan parameter pendukung meliputi suhu inkubasi, $\mathrm{pH}$ medium awal dan akhir inkubasi. Penelitian dilakukan dengan rancangan acak lengkap faktorial (RAL) dengan faktor medium. Hasil penelitian menunjukkan bahwa produksi miselium jamur ling zhi (G. Lucidum) dalam medium air kelapa tua lebih tinggi dibandingkan medium tauge extact broth.
\end{abstract}

Kata kunci: Ganoderma lucidum, Medium, Air Kelapa Tua, Tauge Extract Broth, Kultur Terendam Teragitasi

\section{PENDAHULUAN}

Jamur merupakan organisme heterotrofik yang mempunyai inti, berspora dan dinding sel. Dinding selnya tersusun dari selulosa atau kitin, berbentuk filamen atau benang-benang. Tubuh jamur tersusun oleh filamen-filamen yang disebut hifa. Hifa terdiri atas sel-sel yang berinti satu (uninukleat) atau dua (binukleat). Kumpulan hifa akan membentuk miselium (Alexopoulos et al., 1996; Chang dan Quimio, 1982; Gunawan, 2001). Jamur terdiri dari beberapa divisi, salah satunya adalah basidiomycetes. Anggota divisi basidiomycetes berukuran makroskopis antara lain Volvariela volvacea, Auriculata auricular, Lentinus edodes, Agaricus bisporus, Ganoderma lucidum, Pleorotus ostreatus dan sebagainya.

Ganoderma lucidum biasanya tumbuh pada kayu atau batang pohon (Dube, 2003). Di Indonesia dikenal sebagai jamur kayu atau jamur merah. Jamur ling zhi mengandung berbagai senyawa aktif misalnya senyawa polisakarida, asam amino. Asam askorbat, sterol, alkaloid, asam ganoderik, triterpenoid dan asam oleat
(Alexopoulos et al., 1996). Jamur ling zhi dalam bentuk miselium atau tubuh buah dapat digunakan sebagai bahan dasar obat untuk berbagai penyakit.

Salah satu faktor yang mempengaruhi kesuksesan budidaya jamur ling zhi adalah ketersediaan bibit. Proses pembuatan bibit jamur ling zhi biasanya dilakukan secara konvensional dengan cara menginokulasikan dalam medium sekam gergaji (Aryantha, 1989). Pembuatan bibit secara konvensional membutuhkan waktu yang lama sehingga mempengaruhi produksi biomassa miselium. Selain itu, kemungkinan terjadinya kontaminasi dan degenasi sifat genetik juga relatif lebih besar. Apabila degenerasi sifat dapat dihindari, maka jamur ling zhi yang dihasilkan akan mempunyai sifat genetik yang baik dengan viabilitas yang tinggi.

Salah satu inovasi metode pembibitan yang membutuhkan biaya dan waktu produksi yang sedikit dengan metode kultur terendam karena miselium dari kultur murni dapat langsung ditanam pada media tanam jamur (Wagner et al., 2003). Pada metode ini, potongan tubuh buah atau 
spora jamur diinokulasikan dalam media cair sehingga diperoleh miselium yang lebih banyak dalam waktu yang cepat. Yuliastanti (2011) memperoleh pertumbuhan optimum miseium jamur Pleorotus ostreatus pada kultur terendam teragitasi pada kecepatan $150 \mathrm{rpm}$ selama 96 jam menggunakan medium tauge extract broth (TEB).

Kultur terendam teragitasi menghasilkan pertumbuhan miselium yang cepat dan biaya produksi rendah karena memungkinkan untuk menggunakan medium pertumbuhan yang murah misalnya air kelapa tua (AKT). Air kelapa tua mengandung hormon alami auksin dan sitokinin (Tulecke et al.,1961). Berdasarkan komposisi nutrient terutama adanya hormone alami, maka air kelapa tua (AKT) memiliki potensi untuk menghasilkan miselium yang lebih banyak dibandingkan tauge extract broth (TEB).

\section{BAHAN DAN METODE}

Penelitian ini menggunakan metode terendam teragitasi untuk mengetahui perbandingan produksi miselium jamur ling zhi dalam medium air kelapa tua dan tauge extract broth.

\section{Bahan Penelitian}

Bahan yang digunakan tubuh buah jamur ling zhi ( G. Lucidum) yang berumur 1 bulan yang berasal dari home industry Media Agromerapi Kaliurang Yogyakarta, air kelapa tua,tauge extract broth, $\mathrm{HCl} 0,1 \mathrm{~N}, \mathrm{NaOH} 0,1 \mathrm{~N}$, Alkohol 70\%, aquadest, kloramphenikol, sukrosa dan betadine.

\section{Pembuatan Medium TEB}

Tauge sebanyak 100 gram direbus selama 2 jam dalam 1 liter aquadest, lalu disaring dan diambil filtratnya. Hasil saringan ditambahkan kloramphenikol 0,1 gram dan sukrosa sebanyak 60 gram lalu dihomogenkan. Pengaturan $\mathrm{pH}$ medium hingga $\mathrm{pH} 7$ menggunakan $\mathrm{HCl} 0,1 \mathrm{~N}$ dan $\mathrm{NaOH}$ $0,1 \mathrm{~N}$. Medium dimasukkan sebanyak $50 \mathrm{~mL}$ ke dalam Erlenmeyer $100 \mathrm{~mL}$ kemudian Erlenmeyer ditutup. Medium tersebut disterilisasi dengan autoklaf pada suhu $121{ }^{\circ} \mathrm{C}$ tekanan $2 \mathrm{~atm}$ (Alfiansah, 2005).

\section{Pembuatan Medium AKT}

Air kelapa tua sebanyak $100 \mathrm{~mL}$ disaring. Hasil saringan ditambahkan kloramphenikol 0,1 gram dan sukrosa sebanyak 60 gram lalu dihomogenkan. Pengaturan $\mathrm{pH}$ medium hingga $\mathrm{pH}$ 7 menggunakan $\mathrm{HCl} 0,1 \mathrm{~N}$ dan $\mathrm{NaOH} 0,1 \mathrm{~N}$. Medium dimasukkan sebanyak $50 \mathrm{~mL}$ ke dalam Erlenmeyer $100 \mathrm{~mL}$ kemudian Erlenmeyer ditutup. Medium tersebut disterilisasi dengan autoklaf pada suhu $121^{\circ} \mathrm{C}$ tekanan $2 \mathrm{~atm}$.

\section{Inokulasi eksplan jamur ling zhi}

Tubuh buah jamur ling zhi berumur 1 bulan setelah munculnya primodia, lalu dipotong pada bagian tudung dekat tangkai dengan skapel steril kemudian dipotong berbentuk kubus. Potongan tubuh buah ditimbang seberat 0,25 gram. Eksplan jamur dilewatkan di atas api selama 1 menit lalu dimasukkan ke dalam alcohol 70\% selama 3 menit dan selanjutnya eksplan dicuci berturut-turut dalam larutan chlorox $10 \%$ selama 10 menit, larutan chlorox 5\% selama 5 menit dan larutan chlorox 1\% selama 1 menit. Eksplan dicuci menggunakan larutan betadine (1 liter aquadest ditambahkan 3 tetes betadine) selama 3 menit lalu dibilas dengan aquadest steril. Eksplan dilewatkan di atas api lalu dimasukkan ke dalam medium TEB dan AKT. Setelah itu, Erlenmeyer ditutup kembali menggunakan kapas dan alumuniom foil (Alfiansah, 2005).

\section{Proses kultur terendam teragitasi}

Medium TEB dan AKT yang telah diinokulasi dengan eksplan jamur seberat 0,25 gram lalu diinkubasi selama 8 hari pada rotary shaker dengan kecepatan agitasi 90 rpm pada suhu ruang. Pertumbuhan diamati setiap 2 hari sekali selama 8 hari.

\section{Penimbangan berat kering miselium}

Tahap pertama adalah menyaring miselium menggunakan kertas saring whatsman dengan porositas $0,02 \mathrm{~mm}$ yang telah diketahui berat keringnya. Miselium ditiriskan selama 20 menit lalu dikeringkan dalam oven pada suhu $60^{\circ} \mathrm{C}$ selama 2 hari. Miselium ditimbang menggunakan neraca analitik. Berat miselium diperoleh dari selisih berat kering miselium dalam kertas saring dengan berat kertas saring.

\section{Analisis Data}

Penelitian ini dilakukan menggunakan rancangan acak lengkap (RAL). Berat kering 
miselium yang diperoleh dianalisis dengan uji sidik ragam anova pada taraf uji signifikansi 5\%.

\section{HASIL DAN PEMBAHASAN}

Produksi miselium jamur ling zhi dengan metode kultur terendam teragitasi dalam medium air kelapa tua dan tauge extract broth. menunjukkan adanya pembentukan miselium berupa agregat berwarna putih kekuningan. Hasil penelitian tersebut dapat dilihat pada diagram dibawah ini:

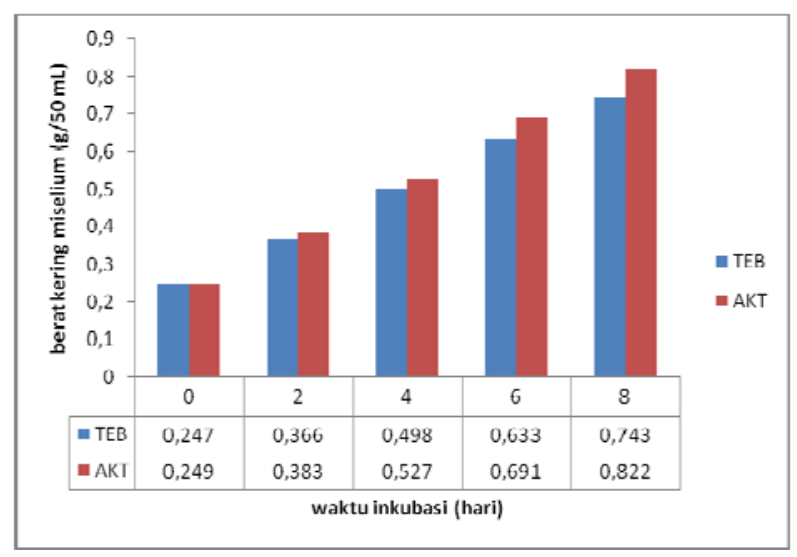

Berdasarkan hasil tersebut, hari ke-0 berat kering miselium dalam kedua medium perlakuan besarnya hampir sama karena hanya berisi eksplan jamur ling zhi. Berturut-turut pada hari ke2 hingga ke-8 miselium dalam medium air kelapa tua maupun tauge extract broth mengalami peningkatan berat kering. Pada hari ke-8 inkubasi, Hal ini menunjukkan bahwa perbedaan medium perlakuan berpengaruh terhadap berat kering miselium. Eksplan jamur telah menggunakan berbagai nutrien dalam medium untuk melakukan aktivitas metabolik untuk menghasilkan sejumlah energi yang penting bagi pertumbuhannya (Alfiansah, 2005). Saat eksplan menggunakan nutrisi yang telah tersedia secara optimal, maka akan menghasilkan miselium secara maksimal.

Berat kering miselium jamur ling zhi yang dikulltur dalam medium air kelapa tua seberat 0,822 gram sedangkan yang dikulltur dalam medium tauge extract broth seberat 0,743 gram. Hal ini disebabkan karena adanya perbedaan beberapa unsur nutrien yaitu karbohidrat dan hormon alami (Dube, 2003). Sebagian fungi dapat menyerap gula sebagai sumber karbonnya (Wagner et al., 2003). Ketersediaan karbohidrat yang lebih besar dalam AKT daripada ekstrak tauge akan memacu proses hidrolisis karbohidrat menjadi piruvat (jalur Embden-Meyerhoff glikolisis). Molekul glukosa akan diubah menjadi 2 molekul asam piruvat. Selanjutnya pembentukkan molekul NADH dan pelepasan energy untuk mensintesis molekul ATP (Charlie dan Watkinsom, 1995).

Air kelapa tua mengandung hormon zeatin yang termasuk dalam kelompok sitokinin, yaitu hormon yang mempunyai kemampuan mendoronng pembelahan sel dan diferensiasi jaringan tertentu (Staden dan Drews, 1974 dalam Tulecke et al., 1961). Oleh sebab itu, medium AKT memiliki potensi sebagai medium produksi miselium jamur ling zhi.

\section{KESIMPULAN}

Produksi miselium jamur ling zhi dalam medium air kelapa tua lebih tinggi daripada medium tauge extract broth sehingga medium AKT memiliki potensi sebagai medium produksi miselium jamur ling zhi.

\section{DAFTAR PUSTAKA}

Alexopoulos, C.J., Mims, C.W dan Blackwell, M. 1996. Introductory Mycology Fourth edition. John Wiley and Sons, Inc. USA. $\mathrm{Pp}: 32-50: 501-508$.

Alfiansah, Y. R. 2005. Produksi Miselium Jamur Ling Zhi (Ganoderma lucidum) pada Kultur Terendam Teragitasi dengn Penambahan Zat Pengatur Tumbuh NAA. Skripsi Biologi MIPA Undip.

Dube, H.C. 2003. An Introduction to Fungi. Vikas Publishing House PVT Ltd. New Delhi. Pp:158-159

Gunawan, A.W. 2001. Usaha Pembibitan Jamur. Penebar Swadaya. Jakarta. Pp:18-26,58-62

Tulecke, W.H., Weintein, L.H., Rutner, A dan Laurencot. 1961. The Biochemical Composition Of Coconut Water As Related Its Use In Plant Tissue Culture. Plant research Inc. New York.

Wagner, R., Mitchell, D.A., Sassaki, G.L., Amazonas, M.A.LA dan Berovic, M. 2003. Current Techniques For Cultivation of 
Ganoderma Lucidum For The Production Of Biomass, Ganoderic Acid And Polysaccharides. $J$ of Food Technol. Biotechno.
Yuliastanti, R. 2001. Propagasi Miselium Jamur Tiram Putih Menggunakan Metode Submerged Dengan Kecepatan Yang Berbeda. Skripsi Biologi MIPA Undip. 